\title{
Pemahaman Hadis Misoginis dalam Kitab Uqudul Lujayn di Pondok Pesantren An-Nur Semarang
}

\author{
Akhmad Khozin \\ Mahasiswa Pascasarjana IAIN Salatiga \\ akmadkhozin11@gmail.com
}

\begin{abstract}
Abstrak
Penelitian ini dilatar belakangi atas problematika di masyarakat yang berkaitan dengan hak-hak dan peran perempuan yang terabaikan, karena indikasi Hadis yang ditafsirkan secara misoginis oleh para mufasir klasik, dari satu sisi menjunjung tinggi martabat perempuan, tapi disisi lain mengebiri hak perempuan dengan cara membatasi peran perempuan dalam kehidupan berumah tangga dan menutup langkah-langkah mereka untuk memberikan kontribusi di lingkungan mereka. Tujuan dari penelitian ini adalah untuk; (1) mengetahui sejauh mana pemahaman santri terhadap Hadis-hadis yang dikaji dalam kitab uqudul lujayn; (2) menggali terhadap pemahaman yang dibangun dalam kajian kitab uqudul lujayn yang berkaitan dengan Hadis misoginis; (3) mengimplikasikan pemahaman tersebut dalam kehidupan sehari-hari. Metode yang digunakan dalam penelitian ini adalah metode kualitatif, dengan menyajikan data lewat verbal dan dituangkan dalam deskripsi, bukan dalam bentuk angka. Hasil penelitian menunjukkan bahwa; (1) santri yang mengkaji kitab uqudul lujayn awalnya belum memahami akan adanya Hadis misogini dan hanya memahami sesuai kitab dan keterangan guru, setelah dilakukan kajian secara mendalam, santri-santri mencoba untuk memahami ulang dengan cara menggabungkan; (2) dalam metode penafsiran klasik dan hermeneutik bisa dipahami bahwa tidak ada Hadis misogini, adanya Hadis yang ditafsirkan secara misogini; (3) pemahaman tersebut terimplikasikan pada kegiatan-kegiatan santriwati an-Nur dalam kehidupan sehari-hari.
\end{abstract}

Kata Kunci: Pemahaman Hadis Misogini, Uqudul Lujayn, Metode Penafsiran Hadis.

\begin{abstract}
This research is based on the problems in society related to the rights and roles of women who are neglected, because the indications of Hadith misogynically interpreted by classical commentators, on the one hand upholds the dignity of women, but on the other hand castrates women's rights by limiting the women's role in marriage life and closing their steps to contribute in the environment. The purposes of this study are; (1) to know the extent to which the students' understanding of the Hadiths studied in uqudul lujayn book; (2) to dig into the understanding built in the study of the lqliya
\end{abstract}


Millatī, Journal of Islamic Studies and Humanities, Vol. 3, No. 1, Juni 2018: 51-72

texts related to the misogynical Hadith; (3) to imply the understanding to everyday life. The method used in this study is a qualitative method by presenting data through verbal and then changed into description form, not numbers. The results showed that; (1) the santri who studied lqya lujayn book initially did not understand the existence of the misogynous Hadith and only understood the book and the teacher's information, after in-depth study, the students sought to re-understand by combining; (2) in the classical and hermeneutic method of interpretation can be understood that there is no misogynist Hadith, but Hadits misogynically interpreted; (3) the understanding is implied on the activities of santriwati an-Nur in everyday life.

Keywords: Misogynist Hadith Understanding, Character Building, Hadith Interpretation Method.

\section{Latar Belakang}

Kitab kuning masih menjadi primadona bagi ajaran turun temurun pondok pesantren yang mempunyai karakter salaf klasik, dengan pengajarannya yang mempunyai ciri khas tersendiri, entah dengan metode bandongan (seorang kyai menerangkan materi kajian kepada santri) atau dengan metode sorogan (santri mengajukan hafalan atau materi yang dipelajari kepada kyai, agar sang kyai menyimak). ${ }^{1}$ Kitab yang dipelajari tersebut mengajarkan tentang pokok-pokok ajaran al-Qur'an dan Hadis, seperti aqidah, tasawuf dan syari'ah, semua itu diterangkan sesuai keahlian para mufasir yang menginterpertasi kitab-kitab tersebut. Dalam penafsirannya juga bervariatif, ada yang fleksibel dan ada juga yang kaku.

Modern ini, pendidikan banyak yang mempunyai pandangan berbeda tentang pemahaman ajaran-ajaran yang mengakar di masyarakat dalam beberapa dekade, semua itu tidak lain karena perkembangan zaman yang ada. Relevansi pendidikan terhadap perkembangan zaman harus representatif, karena jika tidak dilakukan inovasi semua pendidikan yang mapan tersebut terkesan monoton dan kurang tepat guna bagi para peserta didik yang mempelajari ajaran yang disediakan oleh instansi terkait.

Salah satu pendidikan yang disoroti akhir-akhir ini adalah tentang penyetaraan perempuan dalam hak dan peran sosial. Patriarki kaum adami

${ }^{1}$ Zamakhsari "Efektivitas Pembelajaran di Pesantren Mahasiswa; Studi Kasus di Pesantren Aji Mahasiswa al-Muhsin Yogyakarta,"Penelitian Dan Evaluasi, Volume 02. Nomor 03(2000), h. 157. 
dan subordinasi kaum hawa merupakan contohnya, tidak memandang sejauh mana kemajuan peradaban di zaman serba sentuhan tangan ini. ${ }^{2}$ Bagi sebagian kalangan tertentu hal tersebut lumrah adanya, karena menurut mereka memang sudah kodratnya seorang laki-laki itu yang menguasai segalanya dalam rumah miliknya, dan seorang perempuan adalah orang pelengkap yang selalu menjadi second person. ${ }^{3}$ ironinya hal itu pun masuk dalam didikan masyarakat tanpa mereka rasakan, apalagi terkritisi, sehingga pendidikan dianggap tidak ada kontribusi untuk masa depannya. ${ }^{4}$

Potret pendidikan Islam di Indonesia juga tidak luput dengan pendidikan yang mendiskreditkan kaum hawa, seperti adanya Hadis yang ditafsirkan secara misogini, sehingga banyak diantara perempuan yang enggan untuk meneruskan pendidikan lebih tinggi, dengan anggapan sumbangsih pendidikan bagi mereka kurang penting. Disisi lain orang tua yang kurang berpendidikan juga mengajarkan secara turun-temurun tentang posisi perempuan dalam sebuah keluarga dan tugas-tugas yang harus dilakukannya. Perempuan., menurut para orang tua tidaklah lebih dari sekedar pelayan laki-laki dalam menjalankan roda keluarga, sehingga kontribusi ide-idenya kurang penting.

Pondok pesantren sebagai landasan pendidikan agama, merupakan lembaga pendidikan yang syarat ajarannya dengan al-Qur'an dan Hadis, sehingga ada indikasi pembelajaran Hadis yang ditafsirkan secara misoginis. Akan tetapi ada juga beberapa pondok pesantren yang mencoba untuk mereinterpretasikan Hadis-hadis yang dulunya berbau misoginis, salah satunya yaitu pondok pesantren an-Nur, di situ para santri mengkaji dan mereinterpretasi Hadis yang ditafsirkan secara misoginis, karena menurut al-Ghazali Hadis bisa berubah statusnya sesuai dengan qarinah. ${ }^{5}$ Kitab yang dikaji untuk mendalami permasalahan tersebut adalah uqudul lujayn. Kitab tersebut memang mempunyai kelebihan dalam membahas hiruk pikuk rumah tangga, tauhid dan yang lainnya, akan tetapi kitab tersebut mengandung beberapa Hadis yang dianggap misoginis, isinya selain menomor duakan perempuan dalam urusan rumah tangga, disitu juga tidak pernah menjelaskan peran perempuan dalam strata sosial masyarakat,

${ }^{2}$ MansourFakih,Analisis Gender $\mathcal{E}$ Transformasi Sosial,(Yogyakarta: Pustaka Pelajar, 2003), h. 12 .

3 Musahadi, Evolusi Konsep Sunnah Implikasinya Pada Perkembangan Hukum Islam,(Semarang: Aneka Ilmu, 2000), h. 120.

${ }^{4}$ SyafiqHasyim, Hal-hal YangTidak Terpikirkan Tentang Isu Keperempuanan dalam Islam,(Bandung: Mizan, 2001), h. 139.

${ }^{5}$ AminaWadud, Qur'an And Women,(New York: Oxford University Press, 1999), h. 80. 
Millatī, Journal of Islamic Studies and Humanities, Vol. 3, No. 1, Juni 2018: 51-72

yang seharusnya perempuan mempunyai segudang potensi dalam berperan memajukan sosial masyarakat menjadi terhambat, karena dengan adanya tafsir yang mengarah ke misogini, seperti pembatasan bagi perempuan untuk keluar rumah, perempuan melakukan kebaikan atau bahkan beribadah sunah harus ijin suami, dan perempuan harus siap melayani suami kapanpun dan di manapun dia berada. Santri-santri mencoba untuk mereinterpretasikan Hadis-hadis tersebut dalam kajian kitab uqudul lujayn, dengan harapan agar anatara laki-laki dan perempuan memahami bahwa mereka mempunyai hak yang sama dalam menjadi subjek keputusan segala hal yang memang melibatkan kemaslahatan bersama, sesuai dengan prinsip al-Qur'an yang mengutamakan kesetaraan. ${ }^{6}$

\section{Tujuan Penelitian}

Melihat dari latar belakang yang ada di atas, penelitian ini bertujuan untuk mengetahui sejauh mana pemahaman santri pondok pesantren an-Nur tentang Hadis-hadis yang ditafsirkan secara misoginis dalam kitab Uqudul Lujayn, dan sejauhmana pengamalannya dalam konteks sosial zaman sekarang.

\section{Kerangka Teori}

Istilah misogini (mysogyny) secara etimologi berasal dari katamisogynia (Yunani) yaitu miso(benci) dan gyne(perempuan) yang berarti a hatredof women, yang berkembang menjadi Misoginisme (mysogynism), yangbermakna suatu ideologi yang membenci perempuan. ${ }^{7}$ Selain itu istilah misoginidianalogikan berasal dari istilah yang berasal dari bahasa Inggris misogynyyang mempunyai arti yang sama yakni kebencian terhadap perempuan. KamusIlmiah Populer menyebutkan, terdapat tiga ungkapan berkaitan dengan istilahtersebut, yaitu misoginartinya benci akan perempuan, misoginiartinyaperasaan benci akan perempuan, misoginis artinya lakilaki yang benci padaperempuan.Secara terminologi istilah misoginis digunakan untuk doktrin-doktrinsebuah aliran pemikiran yang secara zahir memojokkan dan merendahkanderajat perempuan. Anggapan adanya unsur misoginis dalam hadisdipopulerkan oleh seorang aktivis perempuan Fatima Mernissi melalui bukunya "Women and Islam: An Historical and Theological Enquiry". ${ }^{8}$

${ }^{6}$ Asghfar AliEngineer, Islam And Liberation Theology Essays On Liberative Elements In Islam,(New Delhi: Sterling Publishers, 1990), h. 30.

${ }^{7}$ Sunarto,Televisi, Kekerasan, dan Perempuan,(Jakarta: PT. Kompas Media Nusantara, 2009), h. 49.

${ }^{8}$ Wilaela, "Perempuan-perempuan Haremku: Telaah Pengalaman Perempuan 
Hadis merupakanriwayat yang bertujuan untuk mengutip Nabi dalamsegala hal baik dalam perkataan, perbuatan, dan persetujuan. ${ }^{9}$ Misoginis mempunyai makna membenci atau merendahkan perempuan..$^{10}$ Dalam beberapa tafsir Hadis misogini, perempuan merupakan objek limpahan keputusan bagi laki-laki, dan mereka hanya dianggap sebagai pelengkap bagi kekurangan laki-laki, hal ituberdampak dalam beberapa aspek, seperti kontribusi, hak dan kewajiban suami terhadap perempuan. Keberadaan perempuan sering diragukan perannya dalam kemajuan atau perubahan, seperti hal pendidikan, sehingga pendidikan bagi perempuan dalam pandangan beberapa kalangan kuranglah penting, karena mereka dianggap lemah dalam sisi kognitif, dan cenderung menggunakan perasaan. ${ }^{11}$

Teori Feminisme Liberal. Teori ini berasumsi bahwa pada dasarnya tidak ada perbedaan antara laki-laki dan perempuan. Karena itu perempuan harus mempunyai hak yang samadengan laki-laki. Meskipun demikian, kelompok feminis liberal menolakpersamaan secara menyeluruh antara laki-laki dan perempuan. Dalam beberapahal masih tetap ada pembedaan antara laki-laki dan perempuan.Bagaimanapun juga, fungsi organ reproduksi bagi perempuan membawakonsekuensi logis dalam kehidupan bermasyarakat. Teori kelompok ini termasuk paling moderat di antara teori-teorifeminisme. Pengikut teori ini menghendaki agar perempuan diintegrasikansecara total dalam semua peran, termasuk bekerja di luar rumah. Dengandemikian, tidak ada lagi suatu kelompok jenis kelamin yang lebih dominan.Organ reproduksi bukan merupakan penghalang bagi perempuan untukmemasuki peran-peran di sektor publik.

Teori-teori di atas bisa ditarik kesimpulan bahwa Hadis misoginis adalah Hadis yang mendiskreditkan perempuan dalam penafsirannya, sehingga hak-hak perempuan dan laki-laki tampak timpang dalam peran dan kontribusinya dalam permasalahan sehari-hari, maka melihat dari beberapa aspek, mereinterpretasikan Hadis misoginis sangatlah penting untuk merekonstruksi pemahaman para perempuan yang sebagai objek Hadis misoginis, dan pemahaman laki-laki sebagai kaum yang lebih diuntungkan dengan keadaan tersebut.

oleh Perempuan dengan Pendekatan Sejarah Peradaban Islam”,Marwah, Volume 4. Nomor 8. (2005), h. 22.

${ }^{9}$ Khaled AbuEl-Fadl, The Great Theft: Wrestling Islam from TheExtremists, (Los Angeles: Perfect Bound, 2005), h. 142-143.

${ }^{10}$ Hamimllyas, Perempuan Tertindas? Kajian Hadis-Hadis Misoginis,(Jakarta: The Ford Foundation. 2003), h. xxxii.

${ }^{11}$ Nur JannahIsmail, Perempuan dalam Pasungan Bias Laki-Laki Dalam Penafsiran,(Yogyakarta: Lkis, 2003), h. 86. 
Millatī, Journal of Islamic Studies and Humanities, Vol. 3, No. 1, Juni 2018: 51-72

\section{Metode Penelitian}

Penelitian ini tergolong penelitian field research(penelitian lapangan). Penelitian lapangan merupakan penelitian yang dilakukan secara intensif, terperinci dan mendalam terhadap suatu objek tertentu dengan mempelajarinya sebagai suatu kasus. ${ }^{12}$ Dengan metode ini peneliti akan mengupas tentang penafsiran Hadis secara misoginis dan reinterpretasi yang dilakukan dalam kajian Hadis di pondok pesantren an-Nur.

Subjek penelitian yang dituju yaitu para santri, pengajar dan orang-orang yang ikut dalam kajian pembelajaran Hadis di pondok pesantren an-Nur, dengan informasi yang telah didapat dari santri (informan), peneliti bisa mengumpulkan data yang valid untuk menyusun data secara otentik, karena sumber data utama adalah dari para informan tersebut dan sumber data tambahannya dari kitab dan buku yang dikaji dalam kegiatan belajar-mengajar setiap hari.

Peneliti menggunakan metode intervew sebagai bentuk komunikasi langsung ${ }^{13}$ untuk mengumpulkan data, sebagai alat penggali informasi dari pendidik ataupun peserta didik dalam melakukan kajian-kajian Hadis yang diinterpretasikan secara misoginis, yang telah mereka kaji ulang untuk menuntut relevansi terhadap zaman dan kesetaraan peran antara laki-laki dan perempuan.

Penelitian menggunakan prinsip-prinsip deskriptif sebagai alat penganalisa data. ${ }^{14}$ Dengan prinsip deskriptif tersebut peneliti akan mengumpulkan dan menganalisa data berkaitan dengan interpretasi Hadis misogini yang disusun oleh penafsir klasik, dan untuk menggabungkan dengan kajian terbaru yang ada dalam pondok pesantren an-Nur sebagai reinterpretasi Hadis yang berorientasi ke problematika kontemporer.

\section{Anatomi Kitab Uqudul Lujayn}

Kitab uqudul lujayn mempunyai empat bab udalam pembahasan utamanya, yaitu tentang: Pertama, Hak-hak istri terhadap suami, di dalam bab tersebut menerangkan ayat al-Qur'an dan Hadis tentang besarnya pahala bagi suami ketika bisa memberikan layanan dalam keluarga dengan baik. Kedua, Hak-hak

${ }^{12}$ Lexy J. Moleong, Metode Penelitian Kualitaif, (Bandung: Remaja Rosdakarya, 2005), h. 09 .

${ }^{13}$ W. Gulo, Metode Penelitian dalam Teori dan Praktek, (Jakarta: Rineka Cipta, 1991), h. 86.

${ }^{14}$ Sukardi,Metodologi Penelitian Pendidikan Kpmpetensi dan Praktiknya,(Jakarta: Bumi Aksara, 2009), h. 86. 
wajib suami terhadap istri, di dalam bab ini menerangkan tentang ayat al-Qur'an dan Hadis tentang pahala wanita ketika bisa melayani hak-hak suami, kriteria wanita penghuni neraka dan surga, 11 wasiat Rasul terhadap para wanita, dan buruk dan baiknya perilaku laki-laki dan wanita dalam kehidupan rumah tangga. Ketiga, Keutamaan salat perempuan di dalam rumahnya, dalam bab ini diterangkan tentang haramnya berhias bagi wanita ketika keluar rumah, dan hendaknya wanita itu salat di dalam rumahnya, karena itu lebih baik baginya. Keempat, Haramnya seorang laki-laki memandang wanita selain istrinya, begitu juga sebaliknya. Ada beberapa refleksi pemikiran bagi wanita yang hidup di zaman modern.

Melihat dari bab yang disajikan dalam kitab tersebut, menunjukkan bahwa kitab materinya lebih dominan membahas tentang perilaku perempuan dalam kehidupan berumah tangga, sehingga dalam kajian pondok pesantren an-Nur kitab ini hanya diajarkan kepada santriwati saja.

\section{Peta Pemahaman Santri Tentang Hadis Misogini}

Metode pembelajaran kitab klasik yang selalu menjadi tradisi bagi pondok pesantren salaf seperti bandongan dan sorogan, memberikan kontribusi pemahaman bagi santri terhadap kitab atau hal-hal yang dikaji memang bisa dikatakan kurang kompleks, pasalnya pembelajaran tersebut bersifat doktrinal dan kurang diskursif, sehingga pemahaman yang dihasilkan bersumber dari pemahaman teks dan diwarnai dengan pengembangan dari pemahaman kyai yang membacakan kitab kajian di pondok pesantren, ditambah dengan hasil pemahaman yang beliau kaji sendiri dari kitab-kitab yang mensuport terhadap pemahaman kitab kajian utama, agar tidak memunculkan pemahaman baru yang dianggap berbeda, dan jauh dari batasan-batasan kitab yang diajarkan, karena itu akan menyimpang dari tradisi kehidupan berumah tangga yang dijalani oleh ulama terdahulu.

Pemahaman yang terbangun dalam kajian kitab uqudul lujayn di pondok pesantren an-Nur yang disajikan dengan metode bandungan memang memberikan hasil pemahaman pada santri secara luas tentang masalah kehidupan berumah tangga. Santri terbangun pemahamannya tentang bagaimana cara menjalin kehidupan berumah tangga secara harmonis sesuai dengan pemahaman kitab uqudul lujayn yang diajarkan di pondok-pesantren an-Nur. Santri mengetahui akan hak-hak dan kewajiban sebagai suami dan sebagai istri, tidak sampai hak dan kewajiban saja dalam memahami kitab yang mereka kaji, karena di 
Millatī, Journal of Islamic Studies and Humanities, Vol. 3, No. 1, Juni 2018: 51-72

kitab tersebut membahas juga tentang bagaimana caranya mengatasi masalah dalam kehidupan rumah tangga, ketika dihadapkan suatu permasalahan yang mengindikasikan terhadap ketidak harmonisan dalam kehidupan berumah tangga, sehingga mereka mengetahui cara memecahkan masalah yang suatu saat akan mereka hadapi.

\section{Pembelajaran Kehidupan Berumah Tangga dalam Kitab Uqudul Lujayn}

Kiatab Uqudul Lujayn merupakan salah satu dari beberapa kitab yang menjadi materi pokok yang diajarkan di pendok pesantren an-Nur, karena memang sangat dianggap perlu adanya pembelajaran kitab tersebut, di dalamnya mengajarkan tata cara hidup berumah tangga yang baik, agar menjadi keluarga yang sakinah, mawadah, war rahamah, seperti yang didoakan oleh umumnya muslim di Indonesia bagi para pasangan suami istri yang baru saja mengikat janji suci mereka. Pembelajaran dalam kitab tersebut meliputi aqidah, fiqh ibadah, tata cara berkeluarga (hak-hak antara suami dan istri) dan lain sebagainya. Pemusatan pembelajaran dalam kitab tersebut adalah tentang bagaimana caranya hidup berumah tangga yang baik, seperti apa seharusnya peran laki-laki dalam kehidupan berumah tangga, apa yang mereka harus lakukan dan apa saja kewajiban mereka, dan seperti apa pula hak dan kewajiban seorang wanita dalam kehidupan berumah tangga. ${ }^{15}$

Seperti yang diajarkan didalamnya, bahwa sesorang yang hidup berumah tangga harus selalu mengikuti tuntunan al-Qur'an dan Hadis Nabi Saw, pembelajaran yang ada di dalam kitab Uqudul Lujayn tersebut memang wujud dari penafsiran al-Qur'an dan Hadis, akan tetapi Hadis yang lebih dominan dalam menjadikan hujjah penjelasannya. Kitab tersebut penjelasannya terbagi menjadi empat bab utama, yaitu: hak istri terhadap suami, hak-hak wajib suami terhadap istri, keutamaan salat perempuan di dalam rumahnya, haramnya seorang laki-laki memandang wanita selain istrinya.

Melihat dari isi bab dan sub-sub bab yang diterangkan dalam kitab tersebut, menunjukkan bahwa kitab tersebut lebih dominan membahas tentang perilaku para wanita dalam kehidupan berumah tangga, dan menurut pembelajaran kitab yang dikaji oleh para santri di pondok pesantren an-Nur, kitab tersebut mengandung beberapa Hadis yang ditafsirkan secara misogini,

${ }^{15}$ Wawancara Dengan Sofi pada tanggal 10 September 2017 pukul 14:00 WIB. 
yang sangat jauh dari keadilan yang diajarkan oleh Nabi Muhammad Saw tentang persamaan derajat dan hak manusia di muka bumi ini, seperti peristiwa yang berada dalam keluarga Abdulrahman Wahid, bahwa Sinta, sebagai istri Abdurrahman Wahid memiliki banayak kesempatan untuk menduskisan segala sesuatu dengan suaminya tersebut. ${ }^{16}$ Karena menurut ajaran Nabi yang membedakan derajat manusia adalah ketaqwaan, walaupun memang seorang istri harus taat kepada suami, bukan berarti istri tidak bisa menjadi subjek dalam mengambil keputusan untuk kemaslahatan bersama dalam kehidupan rumah tangga. ${ }^{17}$

\section{Hadis-hadis Misogini yang Terdapat dalam Kitab Uqudul Lujayn}

Kitab Uqudul Lujayn sebagai salah satu referensi bagi orang muslim dalam membangun kehidupan berumah tangga, di dalamnya ada sekitar 89 Hadis, kuwalitas Hadis tersebut bermacam-macam, ada yang shohih dan ada juga yang dho'if. Sedangkan dalam keterangannya, ada yang netral dalam pembagian hak dan kuwajiban, antara suami dan istri, akan tetapi ada juga yang mengarah ke misoginis dalam penafsirannya. Berikut adalah beberapa Hadis yang sering ditafsirkan secara misoginis dalam kitab Uqudul Lujayn:

Hadis tentang laknat Malaikat terhadap istri ketika tidak mau melayani kebutuhan biologis suami

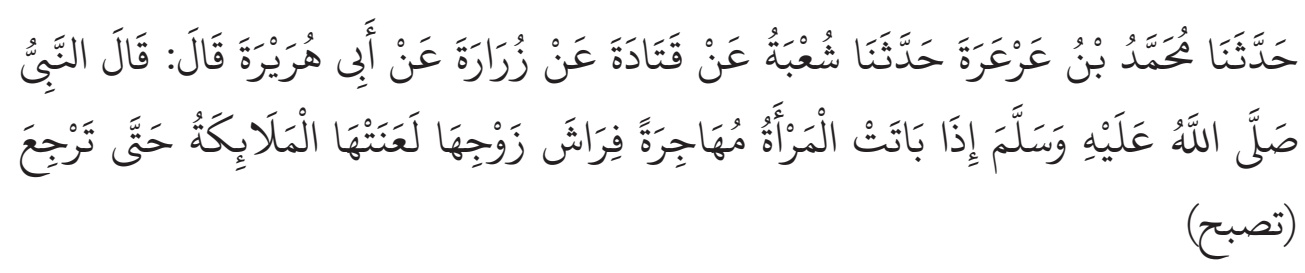

Artinya: "Telah menceritakan kepada kami Muhammad bin 'Ar'arah Telah menceritakan kepada kami Syu'bah dari Qatadah dari Zurarah dari Abu Hurairah ia berkata; Nabi shallallahu 'alaihi wasallam bersabdda: "Apabila seorang wanita bermalam sementara ia tidak memenuhi ajakan suaminya di tempat tidur, maka Malaikat melaknatnya hingga pagi.(H.R Bukhari: 4795).

\footnotetext{
${ }^{16}$ AsfaWidiyanto, "Female Religious Authority, Religious Minority And The Ahmadiyya: The Activism of Sinta Nuriyah Wahid,Journal of Indonesian Islam, Volume 9. Number 1. (2015), h.8. WIB.

${ }^{17}$ Wawancara dengan Desi Ratna Sari pada tanggal 10 September 2017 puklul 13:30
} 
Millatī, Journal of Islamic Studies and Humanities, Vol. 3, No. 1, Juni 2018: 51-72

Hadis tentang wanita dilarang keluar rumah tanpa seijin suami dengan alasan apapun (sehingga membatasi peran sosial dimasyarakat)

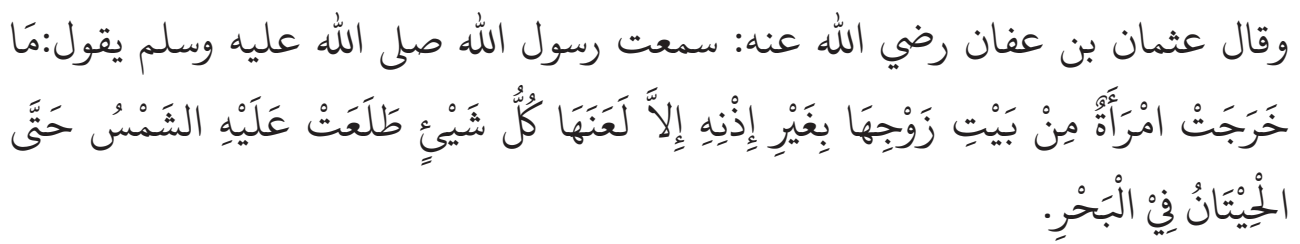

Artinya: "Seorang istri yang keluar rumah tanpa seizin suaminya akan dilaknat oleh segala sesuatu yang terkena sinar matahari hingga ikan-ikan yang ada di lautan”.

Hadis tentang wanita tidak punya Hak untuk meminta talak.

قال أبو بكر الصديق رضي الله عنه، سمعتُ رسولَ اللهِهِ صلى الله عليه وسلم يقول: إِذَا

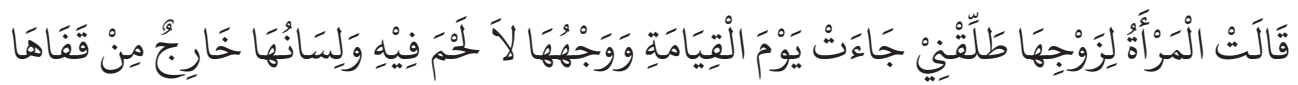

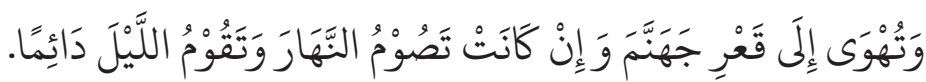

Artinya: "Apabila seorang wanita berkata pada suaminya, Ceraikanlah Aku! Maka ia datang pada hari kiamat dimana mukanya tidak berdaging, lidahnya keluar dari kuduknya, dan terjungkir dikerak jahanam, sekalipun siangnya dia berpuasa dan malam harinya bangun shalat selamanya".

Hadis tentang tidak sah puasa sunahnya seorang istri tanpa seijin suami, sehingga menimbulkan dosa

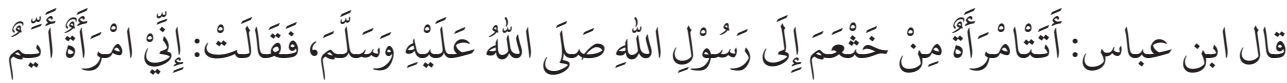

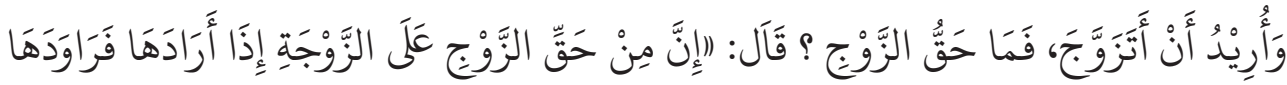

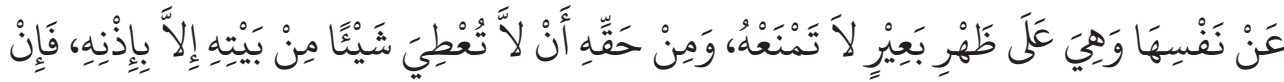

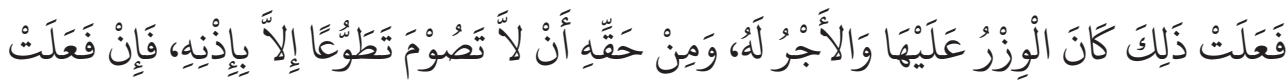

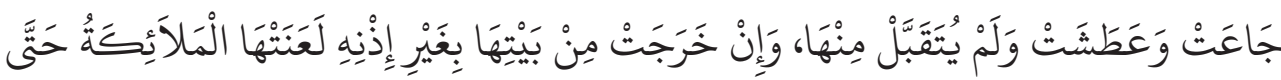

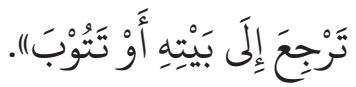

Artinya: "Sesungguhnya dari sebagian hak-hak suami pada istri adalah: 1) apabila suami memerlukan diri istrinya meskipun sang istri sedang berada di atas punggung 
onta, ia tidak boleh menolak. 2) istri tidak boleh memberikan apa saja dari rumahnya tanpa seijin suaminya. Kalau istri memberikan sesuatu tanpa ijin suami, maka si istri berdosa, sedangkan suami mendapat pahala. 3) istri tidak boleh berpuasa jika tidak ijin dari suaminya, karena ia akan merasakan letih dan dahaga, sedangkan puasanya tidak akan diterima Allah. 4) jika istri keluar dari rumah tanpa seijin suaminya, maka dia mendapat laknat para malaikat, hingga kembali kerumahnya dan bertaubat".

\section{Telaah Matan dan Sanad Hadis Kitab Uqudul Lujayn}

\section{Telaah kehujjahan Hadis}

Pembahasan Hadis selalu tidak akan terlepas dengan matan (isi Hadis) dan sanad (rantai periwayat Hadis), Hadis-hadis yang terpaparkan di atas adalah beberapa hadis yang biasanya ditafsirkan secara misoginis di dalam kitab Uqudul Lujayn, beberapa ahli tafsir tidak mempercayai akan adanya Hadis misogini, karena Nabi Muhammad Saw diturunkan di bumi sebagai rahmatan lil 'alamin, sedangkan Hadis sendiri adalah perkataan, perbuatan, dan persetujuan Nabi atas sebuah peristiwa tertentu, yang seharusnya sebagai rujukan untuk sebuah keputusan yang tidak memihak pada siapa pun. Untuk mengetahui bahwa Hadis tersebut memang benar-benar dari Nabi ataukah tidak, karena ada unsur misoginisnya maka haruslah diketahui sanad dan matan Hadis tersebut.

Telaah sanad;dilihat dari segi sanadnya, untuk ke empat Hadis tersebut yang ditemukan dalam kutubus sittah hanyalah Hadis yang pertama, dan ke tiga Hadis yang selanjutnya tidak bisa ditemukan. Hadis yang pertama ditemukan dalam Shohih Bukhar satu Hadis, Shohih Muslim satu Hadis, Musnad Ahmad lima Hadis dan Sunan ad-Darimi satu Hadis. Dari situ bisa diketahui bahwa Hadis yang bisa dianggap sahih hanyalah satu Hadis yang membahas tentang laknat malaikat yang diberikan kepada seorang perempuan yang tidak mau melayani hasrat suaminya ketika dia butuh. Sedangkan ke tiga Hadis selanjutnya, kesahihannya masih dipertanyakan, karena tidak adanya Hadis-hadis tersebut ditemukan dalam kutubus sittah. Padahal jika dilihat dalam kitab Uqudul Lujayn, Hadis-hadis tersebut juga tidak disebutkan rantai perawi Hadis, yang membuat semakin sulit untuk dipercayai bahwa Hadis itu benar-benar dari Nabi, baik secara pemahaman atau pun pelafalan dan penulisannya. Menurut penuturan dari salah satu santri pondok peasantren an-Nur, ${ }^{18}$ jika memang keberadaan sanad dalam Hadis itu sangat berpengaruh dalam memastikan kesahihannya. Jika dalam kitab Uqudul Lujayn memang terbukti ketidak sahihannya Hadis

${ }^{18}$ Wawancara dengan Samsul Bakhri pada tanggal 10 September 2017 pukul 15:00 WIB. 
Millatī, Journal of Islamic Studies and Humanities, Vol. 3, No. 1, Juni 2018: 51-72

tersebut, maka kita bisa mengambil Hadis-hadis dari kitab lainnya sebagai hujjah yang sudah jelas kesahihannya, dan pastinya juga tidak mengandung penafsiran misoginis, sehingga dalam pembahasan kitab tersebut keuntungannya tidak memihak pada satu gender saja, dan bisa menunjukkan kearifan hukum-hukum Islam dalam memahami posisi dan peran masing-masing suami istri dalam kehidupan berkeluarga.

Telaah matan:hadis juga akan dilihat kesahihannya dari sudut pandang matannya. Prinsip Islam, sebagai sebuah agama samawi yaitu agama rahmatan lil alamin (kasih sayang seluruh alam). Berarti jika ada sebuah Hadis yang berisi tentang ketidak adilan di dalamnya, bisa dipertanyakan akan kesahihannya, karena Hadis tersebut jauh dari prisip agama Islam, dan hanya memihak pada sebagian ciptaan Allah saja. Sedangkan Hadis-hadis di atas diartikan dan ditafsirkan secara misoginis, yang mana penafsiran tersebut memojokkan perempuan dalam struktur sosialnya. ${ }^{19}$

Kejanggalan matan Hadis, selain pemahamannya harus dikaji ulang, keasliannya pun juga dipertanyakan, agar bisa diambil titik temunya untuk kemaslahatan bersama, tidak seperti yang dikatakan informan, bahwa Hadis misogini isinya selalu memojokkan kaum perempuan.

\section{Hadis tentang Intervensi Malaikat dalam Hubungan Suami Istri}

Dalam konteks ini harus dilihat dulu, tidak semua wanita akan dilaknat malaikat ketika dia belum bisa melayani suami saat dia membutuhkan. Jika istri memang sedang dalam keadaan tidak memungkinkan untuk melayaninya, maka dia tidaklah berdosa, atau dilaknat oleh malaikat, seperti ketika istri sakit, atau mungkin lelah setelah mengerjakan kesibukannya sehari-hari. Dan ini membutuhkan pengertian dari suaminya, seharusnya seorang suami mempunyai kearifan dan kebijakan dalam mengambil sebuah keputusan, sehingga bisa tercipta kemaslahatan bersama. Seandainya seorang suami terus memaksakan, tidak menutup kemungkinan keharmonisan rumah tangga akan terusik, walaupun dia bisa menikmati keberadaan sesaat dengan halal, tapi efek psikologis istri kemungkinan akan terganggu, dan menyebabkan ketidak nyamanan dalam kehidupan berumah tangga. ${ }^{20}$

\footnotetext{
${ }^{19}$ Wawancara dengan Nur Mufidah pada tanggal 13 September 2017 pukul 08:00 WIB

${ }^{20}$ Wawancara dengan Ahmad Munabah pada tanggal 08 September 2017 pukul 10:00 


\section{Hadis tentang wanita dilarang keluar rumah tanpa seijin suami}

Dalam kajian diskusi, diterangkan bahwa wanita memang harus ijin suami ketika ingin melakukan sesuatu, akan tetapi ijin tersebut juga tidak harus dilakukan setiap saat, asalkan seorang suami sudah mengetahui kegiatan istri dengan adanya ijin yang pertama, maka tidak harus seorang istri ijin untuk yang berikutnya, sehingga ke duanya tidak terbebani dengan batasan masing-masing. Dan serang suamipun biasanya juga akan lebih nyaman ketika istrinya tidak terlalu sering mempertanyakan kebebasannya, dengan catatan ke dua belah pihak saling menjaga kepercayaan masing-masing. ${ }^{21}$

\section{Hadis tentang wanita tidak punya Hak untuk meminta talak}

Sebenarnya sah-sah saja ketika seorang wanita mengajukan talak atau lebih tepatnya khulu', asalkan memang dengan alasan yang tepat, karena walaupun talak itu halal, tetapi itu adalah hal yang dibenci oleh Allah. Pada zaman Rasulullah juga pernah ada peristiwa tersebut, yaitu ketika Ummu habibah minta pada Rasul untuk ditalakkan pada suaminya, dikarenakan wujud fisik suami dan kekurangankekurangan lainnya yang tidak dia sukai, dia beralasan ketika keadaan pernikahan ini diteruskan maka dia takut kalau tidak bisa taat pada suami dan cenderung membangkangnya, sehingga ini akan menjadikan dia masuk neraka. ${ }^{22}$

\section{Hadis tentang tidak sah puasa sunahnya seorang istri tanpa seijin suami}

Tentang tidak sah puasa sunahnya istri ketika dia tidak ijin kepada suami, itu juga melihat konteks permasalahannya juga, ketika seorang suami sudah tahu bahwa istrinya sering melakukan puasa sunah, tidak ijin pun tidak masalah, karena suami sudah tahu kebiasaan seorang istri. Permasalahan di sini biasanya diterangkan, bahwa ditakutkan nanti ketika seorang istri puasa sunah, dan suaminya ingin memuaskan hasrat biologisnya istri tidak bisa, karena sedang menjalani puasa. Dan solusinya, jika memang keinginan tersebut tidak bisa ditahan, maka bukan puasa sunahnya yang dilarang, akan tetapi puasa sunahnya tetap dijalankan walaupun tanpa saijin suami secara langsung, dan jika memang suami menginginkan untuk berhubungan badan, tanggal sang istri membatalkan puasanya, karena perkara sunah tidak bisa mengalahkan perkara wajib. Hukum puasa sunah sendiri tidak menjadi dosa ketika ditinggalkan, sedangkan ketaatan pada suami itu wajib hukumnya. ${ }^{23}$
${ }^{21}$ Ibid.
22 Ibid.
${ }^{23}$ Ibid. 
Millatī, Journal of Islamic Studies and Humanities, Vol. 3, No. 1, Juni 2018: 51-72

\section{Analisis Pemahaman Hadis Misogini}

Pemahaman teks wahyu yang diturunkan oleh Allah kepada RasulNya, atau pun Hadis mempunyai cara pendang yang berbeda-beda. Dalam pemahaman pada masa-masa klasik Islam, seperti ketika Islam berada dalam puncak kejayaannya, mempunyai beberapa metode dalam memahaminya, yaitu dengan menggunakan tafsir. Tafsir pada saat itu ada beberapa macam, yaitu: Tafsir Ijmali, Tafsir Muqaran, Tafsir Tahlili, dan Tafsir Maudu'i, yang masing-masing mempunyai karakter berbeda-beda dalam penafsirannya. Metode-metode penafsiran tersebut selalu dipakai dalam menafsirkan al-Qur'an dan Hadis selama beberapa dekade, pada masa-masa Islam klasik. Seiring dengan perkembangan zaman, metode penafsiran pun juga berkembang, beberapa ilmuan muslim mengembangkan beberapa metode dalam penafsiran al-Qur'an dan Hadis dengan meminjam cara pandang ilmuan-ilmuan non muslim dalam menafsirkannya, seperti Hasan Hanafi Mohammad Arkoun, Farid Esack, dan Nasr Hamid Abu Zaid.

Hermeneutika pembebasan yang dikembangkan oleh tokoh-tokoh muslim kontemporer seperti Hassan Hanafi. Hermeneutika ini dimaksudkan tidak hanya sebagai ilmu interpretasi atau metode pemahaman tetapi lebih dari itu, yaitu aksinya di kehidupan. Menurut Hanafi, dalam kaitannya dengan alQur ' an atau Hadis, hermeneutika adalah ilmu tentang proses wahyu dari huruf sampai kenyataan, dari logos sampai praksis, dan juga transformasi wahyu dari pikiran Tuhan kepada realitas kehidupan manusia. ${ }^{24}$

Penafsiran yang digunakan dalam membahasan Hadis misogini pada saat diskusi di pondok pesantren an-Nur pun tidak jauh dengan metode yang digunakan oleh para ilmuan-ilmuan muslim kontemporer tersebut. Dalam memahami teks-teks Hadis yang ada dalam kitab Uqudul Lujayn, mereka melamula membaca dan memahami persis dengan makna yang ada dalam kitab tersebut, itu sebagai wujud pembangunan fondasi ilmu yang ada, selain itu juga ada sisi ta'dzim kepada pengarang kitab tersebut, sebagai sebuah perwujudan dari rasa bakti seorang murid kepada guru yang telah mengarang kitab yang ada sebagai rujukan untuk melangkah dalam memahami al-Qur'an dan Hadis, atau pun teks-teks penafsiran al-Qur'an dan Hadis yang lain, di kemudian hari.

Proses yang digunakan tersebut memang tidak jauh dengan pemahaman yang digunakan dalam pondok pesantren secara umumnya, karena pendidikan yang ada dalam pondok pesantren tersebut memang berangkat dari pondok pesantren salaf, maka ilmu-ilmu yang diwariskan pun tidak akan jauh berbeda

${ }^{24}$ Hassan Hanafi, Dialog Agama dan Revolusi I, (Jakarta: Pustaka Firdaus, 1994), h. 1. 
dengan pendahulunya. Sedangkan untuk mengembangkan pemahamannya, mereka memadukan penafsiran yang ada dengan ilmu-ilmu yang mereka dapat dari perguruan tinggi. Perguruan tinggi sebagai wujud pemacu paradigma pemikir-pemikir muslim di masa depan, selalu memberikan inovasi-inovasi dalam mengembangkan metode pemikiran dalam menyikapi dan memahami teks dan konteks yang ada dalam kehidupan manusia. Maka untuk memenuhi kebutuhan dan relevansi perkembangan zaman, pemahaman al-Qur'an dan Hadis pun metodenya dipadukan, antara metode-metode penafsiran klasik dan modern.

\section{Implikasi Pemahaman Hadis Misoginis}

\section{Implikasi dalam Kehidupan Rumah Tangga}

Kehidupan berumah tangga merupakan topik utama dalam kitab Uqudul Lujayn. Dalam penjelasannya, dari hampir keseluruhan bab dalam kitab tersebut membahas akan baiknya kehidupan rumah tangga itu seperti apa. Seperti yang telah kita ketahui, bahwa pemahaman awal dalam kitab tersebut ada beberapa Hadis yang penafsirannya dipandang memojokkan peran perempuan pada beberapa bidang kehidupan sosial, seperti perannya dalam rumah tangga itu sendiri.

Kehidupan dalam berumah tangga harus dibangun bersama-sama, baik suami atau pun istri semuanya mempunyai peran sangat penting, sesuai dengan bagiannya masing-masing, memang kadang ada kecemburuan peran dalam kehidupan rumah tangga, dikarenakan tugas dan peran yang berbeda, yang mana memang para laki-laki biasanya pekerjaannya di luar rumah, sedangkan kebanyakan perempuan dalam budaya kita, yang sering kita saksikan, mereka cenderung punya pekerjaan di dalam rumah. Akan tetapi sebenarnya itu bukan berarti tidak adil, karena semua saling melengkapi, layaknya rumah tangga, tidak bisa semua akan bekerja untuk mencari nafkah keluar rumah, akan tetapi salah satu dari suami dan istri harus menjaga rumah dan apa yang ada di dalamnya, termasuk anak-anak sebagai generasi mereka.

Dalam mensikapi penjelasan Hadis yang ada di kitab Uqudul Lujayn, yang dianggap berperan dalam mengubur potensi perempuan dalam perannya terhadap kehidupan sosial, atau pun juga dalam kehidupan berumah tangga. Banyak yang beranggapan, bahwa laki-laki itu mempunyai peran yang lebih penting dan sebagai nahkoda pengatur keluargayang tidak tergantikan, dan tanpa terbantahkan segala keputusannya, sedangkan perempuan hanyalah second 
Millatī, Journal of Islamic Studies and Humanities, Vol. 3, No. 1, Juni 2018: 51-72

person dalam keluarga, mereka tidak lebih dari sekedar pelengkap kehidupan laki-laki yang mana kontribusinya sangatlah kurang penting dalam mengambil keputusan perjalanan rumah tangga. ${ }^{25}$

\section{Implikasi dalam Kegiatan Belajar Mengajar}

Pendidikan di pondok pesantren atau pun di instansi resmi seperti sekolahan dan madrasah semua sangatlah penting bagi seluruh lapisan masyarakat, tidak memandang status sosial, kemapanan ekonomi, atau pun siapa mereka, laki-laki maupun perempuan. Karena semua akan saling melengkapi sesuai kemampuan dan kemauan masing-masing, prinspnya tidak ada seorang pun yang mempunyai keahlian sempurna, semua manusia akan saling membutuhkan antara keahlian yang dimilki oleh satu orang dengan keahlian yang dimiliki orang lain.

Peran perempuan dalam pendidikan juga tidak kalah pentingnya dengan seorang laki-laki yang selalu mempunyai hak patriarki dan mensubordinasikan perempuan dalam beberapa dekade yang telah berlangsung di dalam kebudayaan kita. Di pondok pesantren an-Nur tidak ada perbedaan dalam hak mendapat pendidikan, semua sama, entah dalam mereka mendapatkan ilmu yang biasanya didapat dalam sekolah umum, atau khususnya ilmu agama di pondok pesantren.

Pondok pesantren an-Nur memberikan ruang yang sama antara para santrinya, baik untuk para laki-laki atau pun perempuan dalam mencari ilmu, karena memang sangat dipandang perlu bagi mereka semua, tidak hanya khusus bagi para santri yang laki-laki saja, mengingat kemajaun zaman dan tekhnologi yang ada. Dan selain semua itu, kompleksitas permasalahan dalam seluruh lapisan masyarakat, juga membutuhkan tidak hanya peran laki-laki saja, perempuan sekarang juga mempunyai peran sangat penting di dalamnya, khusunya pendidikan.

Sifat nature dari seorang perempuan yang lemah lembut, penuh kasih sayang, keibuan, kesantunan kata-katanya dan yang lainnya, yang sulit dimiliki oleh laki-laki, itu sangat penting dalam mengsukseskan pendidikan yang ada, khususnya bagi pendidikan anak-anak setingkat PAUD dan sekolah dasar. Sehingga para santrinya tidak dibatasi dalam mengenyam pendidikan, khususnya untuk para perempuan, yang dianggap kurang bisa berkontribusi jika bekerja di luar rumah, agar mereka mempunyai bekal keilmuan yang sama dengan lakilaki, atau peling tidak, mereka bisa mengisi tempat-tempat yang kosong dalam WIB.

${ }^{25}$ Wawancara dengan Ahmad Munabah pada tanggal 10 September 2017 pukul 10:00 
pendidikan yang tidak bisa diisi oleh para laki-laki. ${ }^{26}$

Keluarnya wanita dalam konteks ini seakan-akan menjadi wajib, dikarenakan kepentingan pendidikan tersebut. Para santri disitu pun dianjurkan untuk mengenyam pendidikan setinggi-tingginya, entah itu yang formal atau pun tidak. Bahkan kalau bisa melebihi para laki-laki, karena dari merekalah bibit-bibit anak cerdas di masa depan, karena jika seorang ibu sendiri tidak mempunyai kecerdasan yang mumpuni, bagaimana mereka akan mendidik anakanak suaminya, atau pun anak-anak didik dalam dunia pendidikan secara luas.

\section{Implikasi dalam Bidang Sosial dan Politik}

Keterlibatan para perempuan dalam bidang sosial dan politik dewasa ini sudah menjadi hal yang sangat lumrah. Pasalnya, memang tidak bisa dipungkiri kontribusi para perempuan yang mempunyai keahlian dalam bidang sosial dan politik, yang biasanya hal tersebut diturunkan oleh orang tuanya yang pernah menjadi tokoh di lingkungannya. Pondok pesantren an-Nur pun juga tidak mau menutup mata atas paradigma tersebut, paradigma peralihan gender dalam diri perempuan memang sudah tidak bisa terelakkan, mau tidak mau, harus mengakui akan ketangkasan para perempuan di zaman sekarang dalam perannya di dalam kehidupan sosial masyarakat dan berpolitik, walaupun tidak dalam cangkupan yang luas, seperti di perguruan tinggi atau pun di desa, akan tetapi itu sudah mewakili eksistensi mereka dalam bidang-bidang tersebut.

Realisasi penyetaraan peran di bidang sosial masyarakat dan politik, menurut pengasuh pondok pesantren an-Nur sangatlah perlu untuk diwujudkan, walaupun sering kali, bahkan hampir keseluruhan seorang perempuan harus disibukkan oleh hal-hal yang ranahnya domestik, akan tetapi semua itu tidak menutup kemungkinan peran mereka dalam membantu mensukseskan kegiatan sosial di sekelilingnya. Media sosial, seperti televisi atau pun yang sejenisnya, sudah sering menayangkan para perempuan yang mempunyai peran dalam kehidupan sosial atau pun politik, contoh seperti ibu Kartini, ibu Megawati, ibu Risma atau pun dalam bidang keagamaan seperti mama Dedeh. Keterlibatan mereka tidak bisa dipandang sebelah mata.

Di pondok pesantren an-Nur, di sana juga mengajarkan bagi para perempuan untuk mengembangkan diri dalam bidang sosial dan politik, dalam bidang sosial mereka diajarkan untuk peduli terhadap masyarakat sekitar, mereka selalu dilibatkan dalam kegiatan di masyarakat desa yang terdekat dengan pondok

\footnotetext{
${ }^{26} \mathrm{Ibid}$.
} 
Millatī, Journal of Islamic Studies and Humanities, Vol. 3, No. 1, Juni 2018: 51-72

pesantren, entah mereka harus berkontribusi seperti apa dalam kegiatan tersebut, yang penting mereka mau ikut membantu untuk mensukseskan acara yang ada di desa tersebut. Karena di selain mengajarkan kepedulian mereka terhadap sesama, juga mengajarkan mere secara langsung dalam kehidupan nyata, bagaimana cara berinteraksi dengan orang yang mempunyai latar belakang karakter dan dunia pendidikan yang berbeda beda, tidak seperti di pondok atau perguruan tinggi, yang mena orang-orang yang hidup dalam satu instansi biasanya, pemikiran dan karakter antara satu dengan yang lainnya tidak jauh berbeda, walaupu ada perbedaan, itu masih mudah untuk dipersatukan dalam satu visi.

Berpolitik, mungkin itu masih sangat terlalu jauh jika dikaitkan dengan para santri di pondok pesantren an-Nur, akan tetapi tidak menutup kemungkinan bagi para santrinya juga bisa berkontribusi dalam bidang tersebut, begitu juga para santri putri. Memang di sana tidak pernah ada materi yang diajarkan terkait perpolitikan dalam kegiatan belajar mengajar setiap hari. Peraturan pondok pesantren an-Nur tidak terlalu mengekang para santrinya untuk mengikuti kegiatan di perguruan tinggi agar santri-santri bisa mengeksplor pelajaran dan keterampilan yang ada, seperti mengikuti organisasi yang sifatnya mengembangkan potensi dan bakat santri sebagai mahasiswa, dan juga mengikuti organisasi yang mempunyai latar belakang politik, seperti SEMA dan DEMA. ${ }^{27}$

Pemahaman akan Hadis yang tidak kaku menjadi kunci dari semua peraturan di pondok pesantren tersebut. Karena memang sebenarnya Hadis Nabi itu semua membawa kemaslahatan bersama, sehingga tidak mungkin ketika ada beberapa Hadis mempunyai keterangan yang akan memojokkan golongan atau orang tertentu, sedangkan kita sendiri meyakini, bahwa Hadis adalah tuntunan hidup nomor dua setelah al-Qur'an bagi orang-orang muslim, mana mungkin sebuah tuntunan yang sudah dijamin oleh Nabi, ketika mengikutinya akan masuk surga, akan memberikan ketimpangan dan ketidak adilan dalam realisasinya.

\section{Implikasi Pemahaman Hadis Misogini}

Dalam membangun pemahaman kitab yang membahas tentang keharmonisan hidup berumah tangga, di pondok pesantren an-Nur, santri-santri mengkaji kitab Uqudul Lujayn, disuguhkan dengan metode diskusi, agar mereka semua ikut berpartisipasi dalam memahami Hadis yang ada dalam kitab tersebut. Terlepas akan kontribusi ilmu yang diberikan bisa mewakili kebutuhan umat muslim secara luas atau tidak, yang penting mereka sudah mengupayakan pemahaman

\section{${ }^{27}$ Ibid.}


Hadis misogini, agar bisa membawa kemaslahatan bersama dalam kehidupan berumah tangga.

Pemahaman yang dibangun dalam kitab tersebut dipusatkan pada Hadishadis yang dipandang berpengaruh untuk memojokkan orang perempuan dalam lingkungan keluarga atau peran sosialnya dalam masyarakat, dengan kata lain pembahasan berpusat pada Hadis misogini. Dari teks yang ada, yang merupakan pemahaman sujektif dari seorang penafsir (pembaca) dan pengarang kitab dijadikan satu, dengan tujuan kemaslahatan untuk menggali hukumnya, karena jika hanya mengedepankan pengarang kitabnya saja, tanpa kontribusi dari penafsir yang membacanya, itu hanya akan menghasilkan kajian kehidupan konteks zaman dahulu saja, berbeda seandainya penafsir juga ikut memberikan sumbangsih dari teks Hadis asli, setelah itu dipadukan dengan pemikiran pengarang kitab tersebut, dan penafsir memberikan kontribusi intelektualnya dalam menafsirkan teks tersebut, berdasarkan konteks kultur sosial dan zamannya, karena semakin banyak penafsiran yang digunakan dan teks itu sendiri, akan semakin objektif hasilnya.

Pemfokusan penelitian adalah pada Hadis misogini yang mambahas tentang: Pertama, laknat Malaikat yang ditujukan kepada perempuan, atau seorang istri yang tidak mau melayani suami ketika diajak melakukan hubungan badan. Kedua, pembahasan mengenai dilarangsa seorang istri keluar dari rumah suaminya, tanpa izin terlebih dahulu. Ketiga, seorang wanita tidak punya haq untuk mengajukan gegatan cerai kepada seorang suami, jika dia melakukannya akan dilaknat oleh semua makhluk Allah. Dan keempat, seorang istri tidak boleh puasa sunah tanpa seijin suami, apabila dia melanggarnya (ijin) kepada suami, maka dia akan mendapat dosa atas puasanya, dan puasanya tidak lain hanya mendapat lapar dan dahaga.

Analisis implikasi pemahaman Hadis yang dijadikan pembahasan pokok di pondok pesantren an-Nur, untuk diaplikasikan pada kehidupan sehari-hari, memberikan ruang bagi perempuan untuk ikut andil dalam kehidupan bersosial di berbagai lapisan masyarakat atau dalam keluarganya sendiri, seperti:kehidupan berumah tangga, dunia pendidikan, perekonomian, dan sosial politik.

Kontribusi dari metode penafsiran yang dipadukan dari berbagai konteks sudut pandang, untuk memahami teks-teks Hadis tersebut dengan langkah sebagai berikut, pertama melibatkan teks Hadis itu sendiri dan seterusnya dipadukan dengan teks-teks pemikiran yang dituangkan oleh pengarang kitab Uqudul Lujayn, setelah itu ditambahkan kontribusi pemikiran dari penafsir 
Millatī, Journal of Islamic Studies and Humanities, Vol. 3, No. 1, Juni 2018: 51-72

(peserta diskusi), maka menimbulkan empat implikasi di atas. Sehingga dengan penafsiran tersebut peran perempuan pun menjadi terlihat, dan lebih realistis ketika dilihat dari struktur sosial yang ada dalam lingkungan masyarakat, berbeda ketika hanya dipahami dari sudut pandang penafsir awal (pengarang kita), yang memungkinkan hanya melihat dari sudut pandang sosial yang pernah ada di masanya, atau masa sebelumnya, dan hanya memberikan sedikit pandangan bagi masa-masa setelahnya, yang bisa menjadi sangat jauh berbeda kalau dilihat dari kemajuan zaman dan perkembangan kehidupan sosial saat ini.

\section{Simpulan}

Hadis misoginis yang terdapat dalam kitab uqudul lujayn memberikan pengaruh terhadap cara berpikir bagi orang yang mengkajinya, termasuk para santri di pondok pesantren, khususnya pondok pesantren an-Nur. Berikut adalah inti dari hasil penelitian yang telah dilakukan:(1) Pemahaman para santri an-Nur terhadap Hadis misogini sudah hampir merata, hampir semua santri yang diwawancarai memahami Hadis tersebut, karena memang dalam kajian kitab uqudul lujayn pernah dibahas tentang Hadis tersebut.(2) Kajian yang digunakan dalam membahas Hadis misoginis di pondok pesantren an-Nur menggunakan metode klasik, seperti bandongan, akan tetapi untuk mengembangkan kajian tentang Hadis tersebut agar hasilnya bisa maksimal dan lebih aplikatif sesuai zaman dan kultur sosialnya, para santri menggunakan metode diskusi. Dalam diskusi tersebut, tidak hanya metode tafsir klasik saja yang digunakan untuk memahai, tapi juga sedikit mengambil metode tafsir hermeneutikanya Hasan Hanafi.(3) Implikasi dari Hadis yang ditafsirkan secara misoginis tersebut, setelah dikaji dan dipahami ulang oleh para santri, menunjukkan indikasi bahwa tidak ada Hadis dari Rasulullah bersifat misoginis, hanya saja tergantung para mufassir menafsirkan Hadis tersebut. Sehingga hasil dari penafsiran tersebut menunjukkan adanya implikasi untuk peran perempuan sebagai subjek dari segala keputusan dalam rumah tangga, dan pengakuan atas eksistensi perempuan terhadap kepentingan sosial di luar rumah.

\section{Daftar Pustaka}

Aflaha, Umi. "Kajian Hadis dalam ormas-ormas Islam di Indonesia Analisa Pemahaman NU dan Muhammadiyyah terhadap Hadis-hadis Misoginis". Tesis. UIN Yogyakarta. 2011. 
El-Fadl, Khaled Abu. The Great Theft: Wrestling Islam from TheExtremists.Los Angeles: Perfect Bound. 2005.

Engineer, Asghfar Ali. Islam And Liberation Theology Essays On Liberative Elements In Islam. New Delhi: Sterling Publishers. 1990.

Fakih, Mansour.Analisis Gender $\mathcal{E}$ Transformasi Sosial.Yogyakarta: Pustaka Pelajar. 2003.

Gulo, W. Metode Penelitian dalam Teori dan Praktek. Jakarta: Rineka Cipta. 1991. Hassan Hanafi, Dialog Agama dan Revolusi I, Jakarta: Pustaka Firdaus, 1994.

Hasyim, Syafiq. Hal-hal YangTidak Terpikirkan Tentang Isu Keperempuanan dalam Islam. Bandung: Mizan. 2001.

Ilyas, Hamim.Perempuan Tertindas? Kajian Hadis-Hadis Misoginis. Jakarta: The Ford Foundation. 2003.

Ismail, Nur Jannah.Perempuan dalam Pasungan Bias Laki-Laki Dalam Penafsiran. Yogyakarta: Lkis. 2003.

Jamilah. Marriage and The Independency of Women (A Case Study On Early Marriage In Local Area In Madura). Egalita. Volume 02. Nomor 02. (Juli, 2012).

Moleong, Lexy J. Metode Penelitian Kualitaif. Bandung: Remaja Rosdakarya. 2005.

Musahadi. Evolusi Konsep Sunnah Implikasinya Pada Perkembangan Hukum Islam. Semarang: Aneka Ilmu. 2000.

Mussaif, Muzakka. "Kesetaraan Gender dalam Sastra Pesantren (Kajian terhadap Kitab Syi’ir Laki Rabi)”. Nusa. Volume 12. Nomor 2. (Mei 2017).

Rofiq, Muhamad. "Studi Hadis Yang Menyamakan Antara Keledai, Anjing Dan Perempuan”. Memahami Hadis Misoginis Perspektif Maqasid Syari'Ah. Volume 16. Nomor 01. (April. 2015).

Said, Hasani Ahmad. "Wacana Pemahaman Hadis, Menggali Akar SosioKultural”. Hadis Misoginis. Volume 06. Nomor 01. (Januari. 2012).

Sukardi. Metodologi Penelitian Pendidikan Kpmpetensi dan Praktiknya. Jakarta: Bumi Aksara. 2009.

Sunarto. Televisi, Kekerasan, dan Perempuan. Jakarta: PT. Kompas Media Nusantara. 2009.

Wadud, Amina. Qur'an And Women. New York: Oxford University Press. 1999. Widiyanto, Asfa. "Female Religious Authority, Religious Minority And The Ahmadiyya: The Activism of Sinta Nuriyah Wahid. Journal of Indonesian Islam. Volume 9. Number 1. (June 2015). 
Millatī, Journal of Islamic Studies and Humanities, Vol. 3, No. 1, Juni 2018: 51-72

Wilaela. "Perempuan-perempuan Haremku (Telaah Pengalaman Perempuan oleh Perempuan dengan Pendekatan Sejarah Peradaban Islam)”. Marwah. Volume 4. Nomor 8. (Juli. 2005).

Zamakhsari."Efektivitas Pembelajaran di Pesantren Mahasiswa (Studi Kasus di Pesantren Aji Mahasiswa al-Muhsin Yogyakarta)”. Penelitian Dan Evaluasi. Volume 02. Nomor 03. (Februari, 2000). 